\title{
Aisthesis
}

Firenze University Press

www.fupress.com/aisthesis

OPEN ACCESS

Citation: S. Šurbatović (2021) Alteration of the Touch Into a Gaze - Reading Through the Drawing. Aisthesis 14(1): 57-69. doi: 10.36253/Aisthesis-12773

Copyright: ( 2021 S. Šurbatović. This is an open access, peer-reviewed article published by Firenze University Press (http://www.fupress.com/aisthesis) and distributed under the terms of the Creative Commons Attribution License, which permits unrestricted use, distribution, and reproduction in any medium, provided the original author and source are credited.

Data Availability Statement: All relevant data are within the paper and its Supporting Information files.

Competing Interests: The authors have declared that no competing interests exist.

\section{Alteration of the Touch Into a Gaze - Reading Through the Drawing}

\author{
Sonja Šurbatović \\ Complutense University \\ sonja.surbatovic@gmail.com
}

\begin{abstract}
Studying the touch as a sense developed by contact, and the necessity to redefine it, due to the global pandemic and social dissonance that occurred is the topic of this text. Questioning the approach to drawing under the influence of remoteness addresses the need to look closely, to get personal with the drawing, a manifestation of experience. Drawing of intimacy, evaluate concepts of encounter and isolation posing the question of whether we can experience the closeness of the other through the embodiment of the experience in the drawing. Re-examining tactile sensation observed through the obstacle of corporeal distance, a reflection of intimate experiences and spaces opens up for a new interpretation - of touch without the touch. Can this obstacle transform touch into gaze; and can an image in its making, construct a tactile sensation? Intertwining theoretical and practical approach, this text witness drawing and its visual consumption in space of violated closeness.
\end{abstract}

Keywords: drawing, tactile, intimacy, touch, absence.

\section{INTRODUCTION}

This text deciphers intimacy within a drawing and points to the relationship of gaze and touch. The concept of proximity, violated by the newly imposed physical distance, created the shortage of intimacy, therefore, touch. To analyze drawing in these anxiety-enhanced events, the intention is to strip off the process of drawing and to analyze the changes in intensity, and try to explore the connections under the influence of the constant shift of presence/absence, touch/gaze.

\section{MEANING OF ABSENCE}

«Absence [noun]: a state or condition in which something expected, wanted, or looked for is not present or does not exist; is absent» (Merriam Webster, 2021). Like one of the main concepts, absence arose as an expression, since all humankind is experiencing 
it through some kind of shortage, of something or someone, while paradoxically, virtually we are at one's fingertips. Revealing our personal space, we are exposing the intimate, and at the same time, we are cut off genuine intimacy, through inflicted limitations. The new discipline we are experiencing is based on power technology and its anatomy, through the exercise of a set of different techniques, and regimes (Foucault [1977]: 215-216) imposed on people on many levels; regarding the spread of a virus, corporeal distance, global trade and economy, geopolitical or pharmaceutical battle... Introducing tests or Covid Ausweis/passport can have its benefits for some, on the other hand, questioning the surveillance apparatus, like Deleuze took notice of Guattari's idea of the city

where one would be able to leave one's apartment, one's street, one's neighborhood, thanks to one's (dividual) electronic card that raises a given barrier; but the card could just as easily be rejected on a given day or between certain hours; what counts is not the barrier but the computer that tracks each person's position - licit or illicit - and effects a universal modulation. (Deleuze [1992]: 7)

Surely, pandemics changed everything, regarding the contacts, depending on the country, they were/are, inevitably forbidden globally. Whether, you share views on control of the human population, like the ones from the authors mentioned above, or the one from Žižek, who says that "those in charge of the state are in a panic because they know not only that they are not in control of the situation, but also that we, their subjects, know this. The impotence of power is now laid bare» (Žižek [2020]: 123).

The predicament of the pandemic and lockdowns has its cost, leads to overexposing that became unavoidable in solitude. Are we learning something new, did we get smarter? According to Hegel's well-known quote about learning from history, most likely, no. In the situation where our room becomes our cell, we unveil ourselves, trying to redefine notions of distance/proximity through lack of touch. Like with some odd form of collective escapism that is inflicted on us, tactility became questionable. The distance and imposed solitude can be deciphered through drawing and its instruments, in a situation where experiencing others through our thoughts, the link with our close ones can be even more intense (Žižek [2020]: 3).

\section{INTRODUCING THE NEW TOUCH}

In an article dealing with the topic of disability studies, Georgina Kleege explained the interesting process of drawing based on touch in the exercise called «Blind Contour Drawing». The students followed the contour of an object with their eyes and were making a drawing with charcoal without looking at the paper. She said «while the eye seeks the outline of the object, the hand does not. The hand embraces the object in its multifaceted complexity» (Kleege [2013]: 3).

Exploring the drawing as a form of a memoir, a diary in the moment of stillness, reflects on the situations of common life. Since detaching from our prior life is impossible, one can recall it through basic materials - charcoal and pencil, paper, where freezing of experiences and reproducing the images and events happens. «To see, to perceive, is more than to recognize. It does not identify something present in terms of a past disconnected from it. The past is carried into the present so as to expand and deepen the content of the latter» (Dewey [1980]: 24-25).

Maybe the process should be inverted, erasing pictures since the memory is fading with time. And the absence of others is more intense and noticeable. However, the habitual meditative method produces delicate scenes of intimacy, and impenetrable blackness echoes the intensity of the moment. "The sense of touch is perceived as annihilating both space and time. This oft-perceived ability of touch to bridge space and time gave it a special value » (Classen [2012]: 142). Giving drawing this temporal quality, the intention was to connect events that happened and the ones that are prevented by the new circumstances. Drawing the shapes, creating them by repetitive strokes is 
the process of evoking the touch, closeness of the other. Through repeating the action, putting pressure on the paper with mechanical repetition of strokes elicits a resemblance of contact, pressure, rub.

\section{METHOD OF DRAWING}

The topic in my works included in this paper deals with the issue of intimacy (fig. 1-10). The question of intimacy could be observed from different standpoints and might be disseminated through multiple terms. The motives presented, can be understood differently if we take into consideration possible spatial and temporal distance, for example. Are we near to the one we are fixing our eyes on, or we are separated by time or space or another kind of obstacle? Some of the images included are older than a year, but since they were made in the absence of the other, to put things in context they were included intentionally (fig. 6-10).

There are many examples of how drawings were made, or at least finished, distant from the scene they first occurred, like a famous bullfight

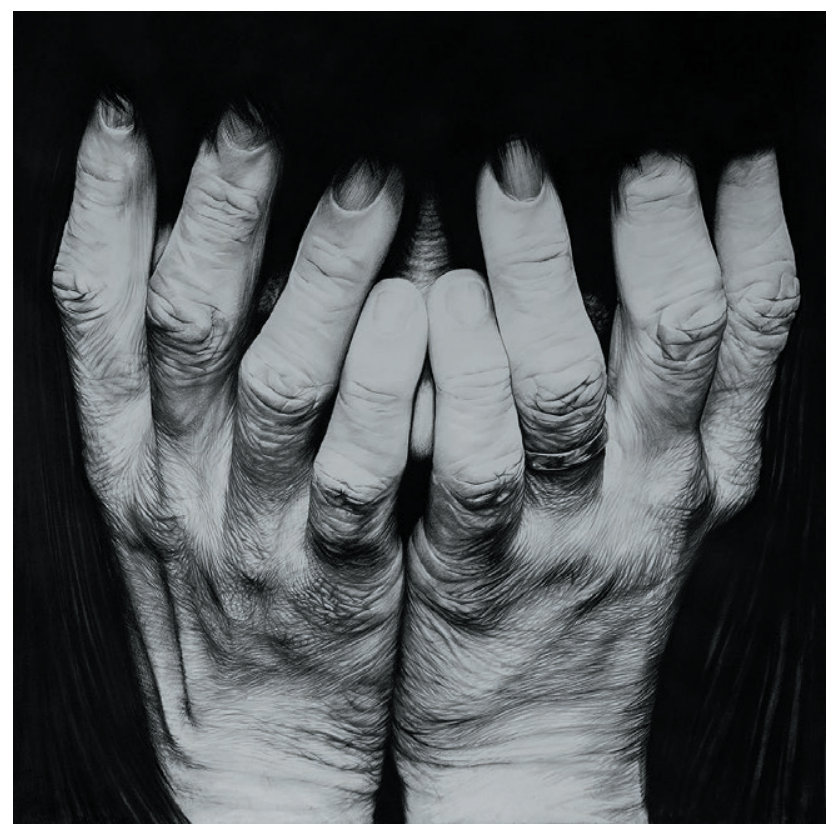

Fig. 1, Sonja Šurbatović, Mother, 2020, charcoal on paper, $100 \times 100 \mathrm{~cm}$ from Goya, The Agility and Audacity of Juanito Apinani in the [Ring] of Madrid. He had limited time to put everything on paper while witnessing it, so he had to return to it later, fixing parts, overdrawing, giving it a final touch (Petherbridge [2010]: 90-91). Either it is a matter of sketching as a fast record or some more studious and detailed method, different circumstances demand a different kind of approach. The process of the works proposed held place away from the ones they were embodying. Needless to say that besides the absence, which is critical, the author is always drawn to the details and complex imagery, therefore durable practice is crucial. However, during creation, unnecessary is striped, and very few elements are kept in focus, and details are intensely developed on them. Taking into account the current situation with covid lockdowns, distance

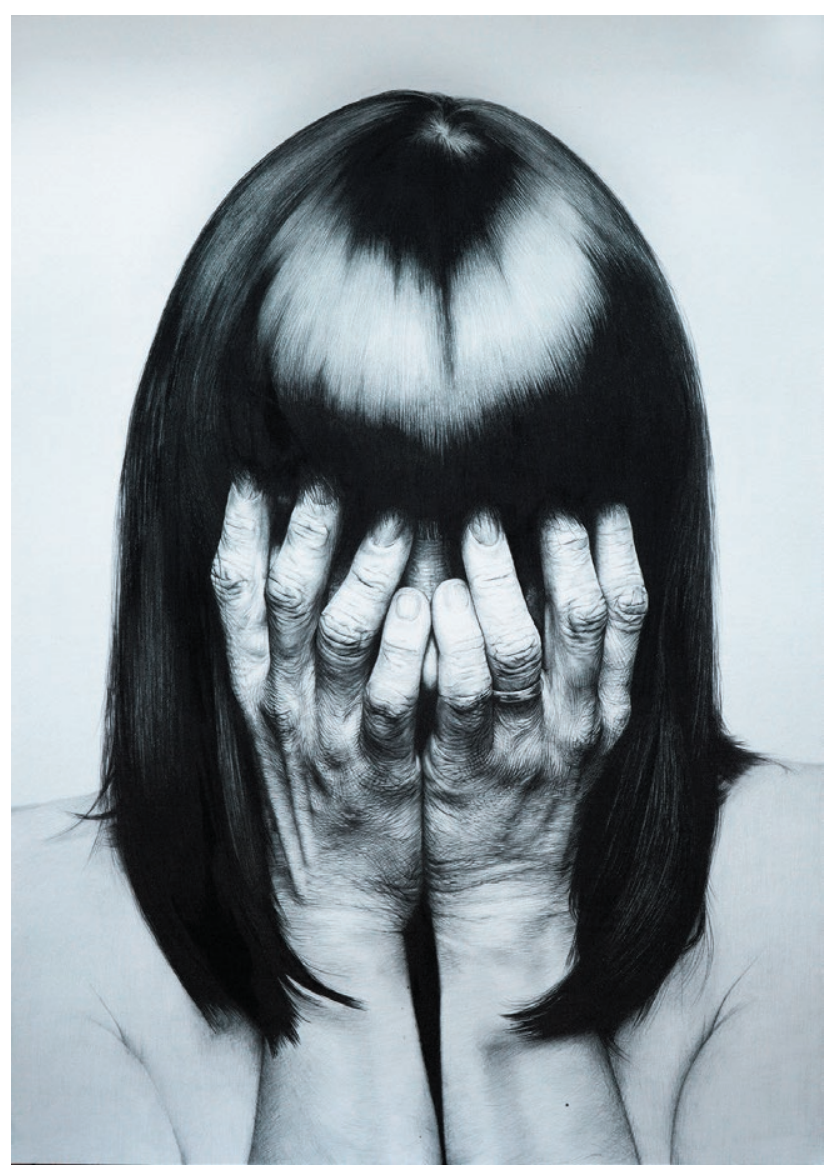

Fig. 2, Sonja Šurbatović, Angst, 2017, charcoal and pencil on paper, $70 \times 100 \mathrm{~cm}$. 


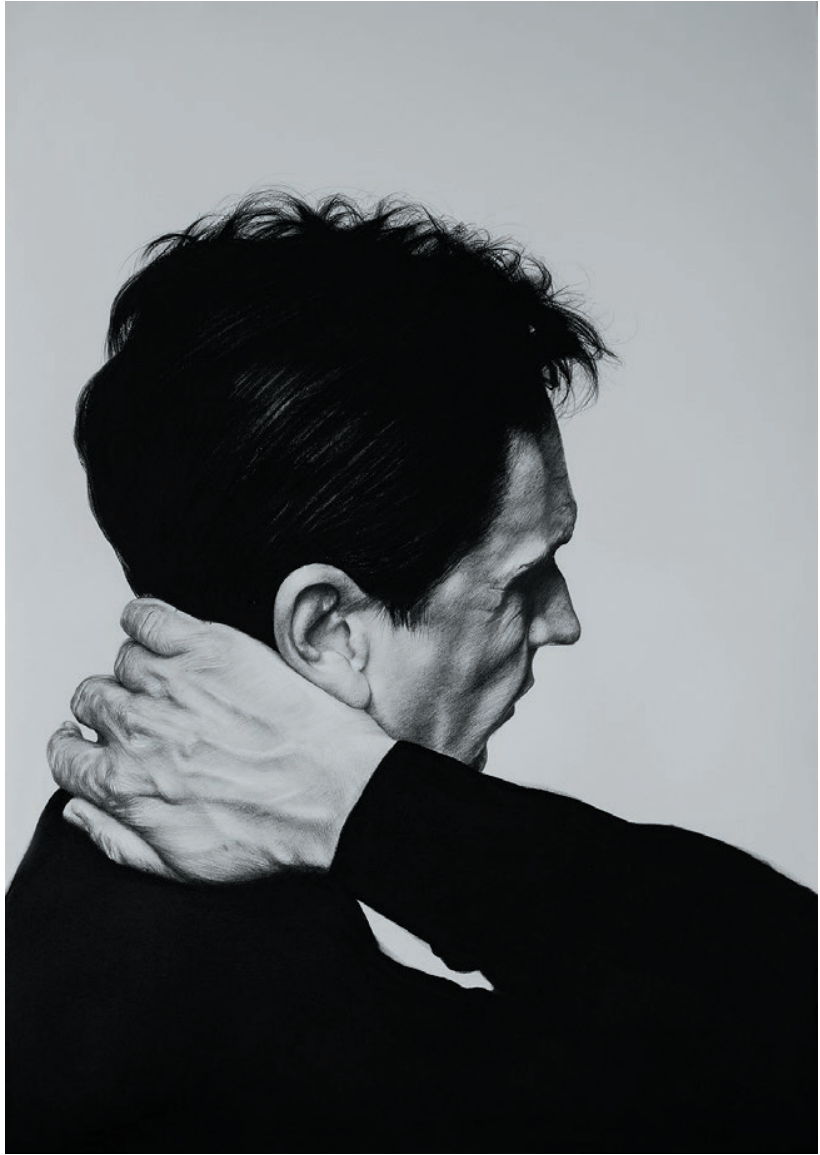

Fig. 3, Sonja Šurbatović, Untitled, 2020, pencil and charcoal on paper, $70 \mathrm{x} 100 \mathrm{~cm}$.

in any form is mandatory, and more demanding practice is desirable.

The artist with a distinguished body of work, that this particular situation is relatable to is Louise Bourgeois, as Roberta Smith called her once, the «force of nature» (Smith [2017]) because of her prolific practices and narratives in different fields. The last years of her life, maybe even a decade, she spent locked inside of her house which was her studio as well, under the influence of agoraphobia that she suffered from. Some say it was triggered by her father's death in 1951 and was followed by depression, too. Of course, we could say that her condition was imposed on her from the outside but it can't be identified the same way as current lockdowns. Even if it was initiated by this event, it was imposed from the inside. One could say that the significant association lies exactly in this con-

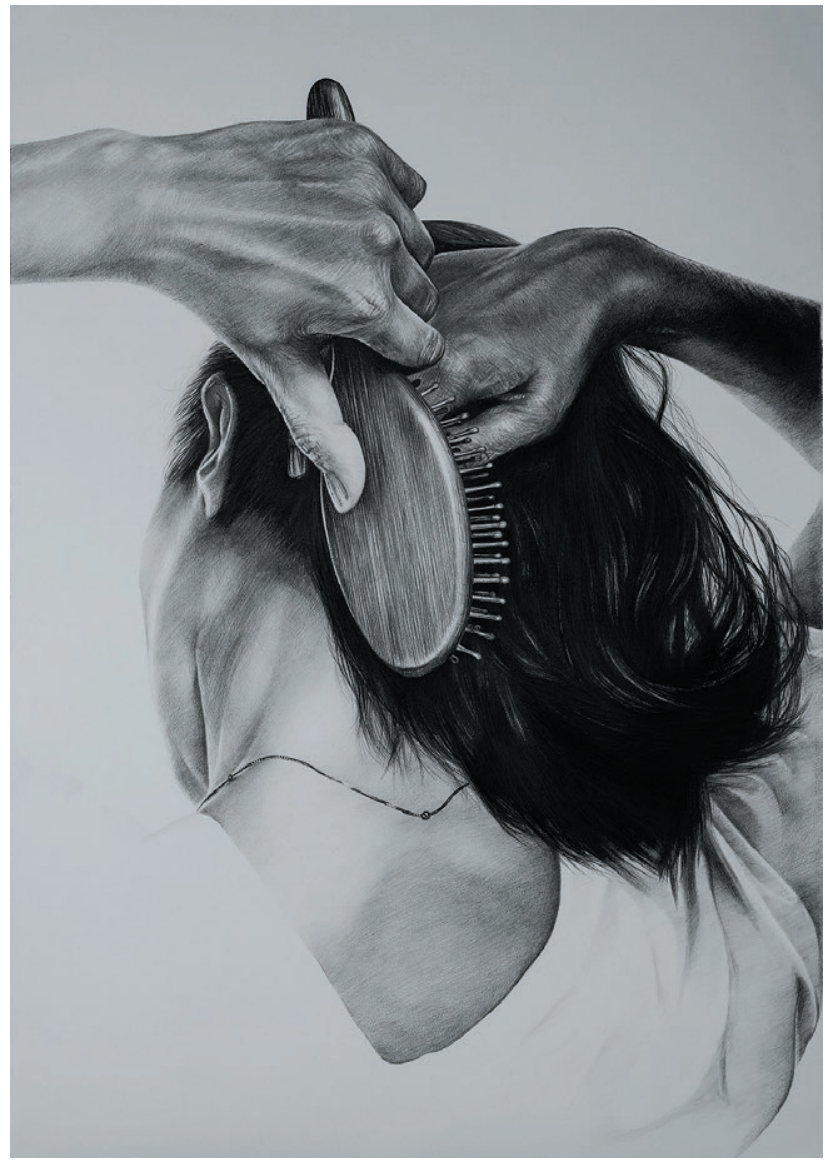

Fig. 4, Sonja Šurbatović, Untitled, 2020, pencil and charcoal on paper, $70 \mathrm{x} 100 \mathrm{~cm}$.

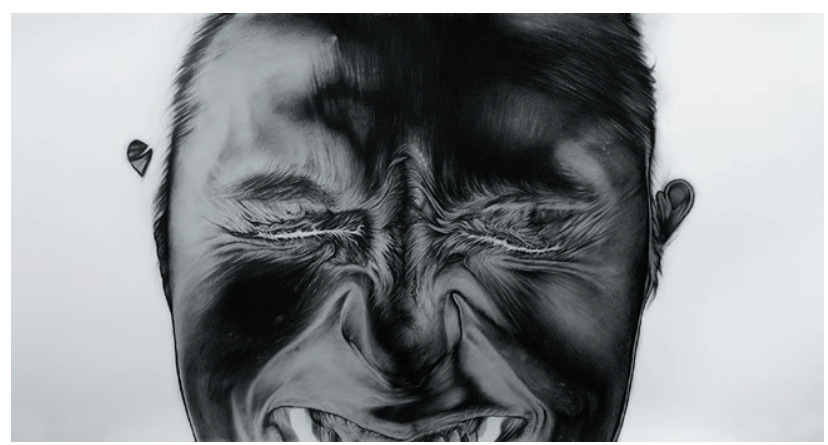

Fig. 5, Sonja Šurbatović, Untitled, 2020, pencil and charcoal on paper, $130 \times 70 \mathrm{~cm}$

nection of her work with cells, recalling enclosed spaces, prison lookalike. Referring to her work is not supposed to be correlated to the technical manifestation of it, but the feeling of disconnection, fear, and anxiety. 


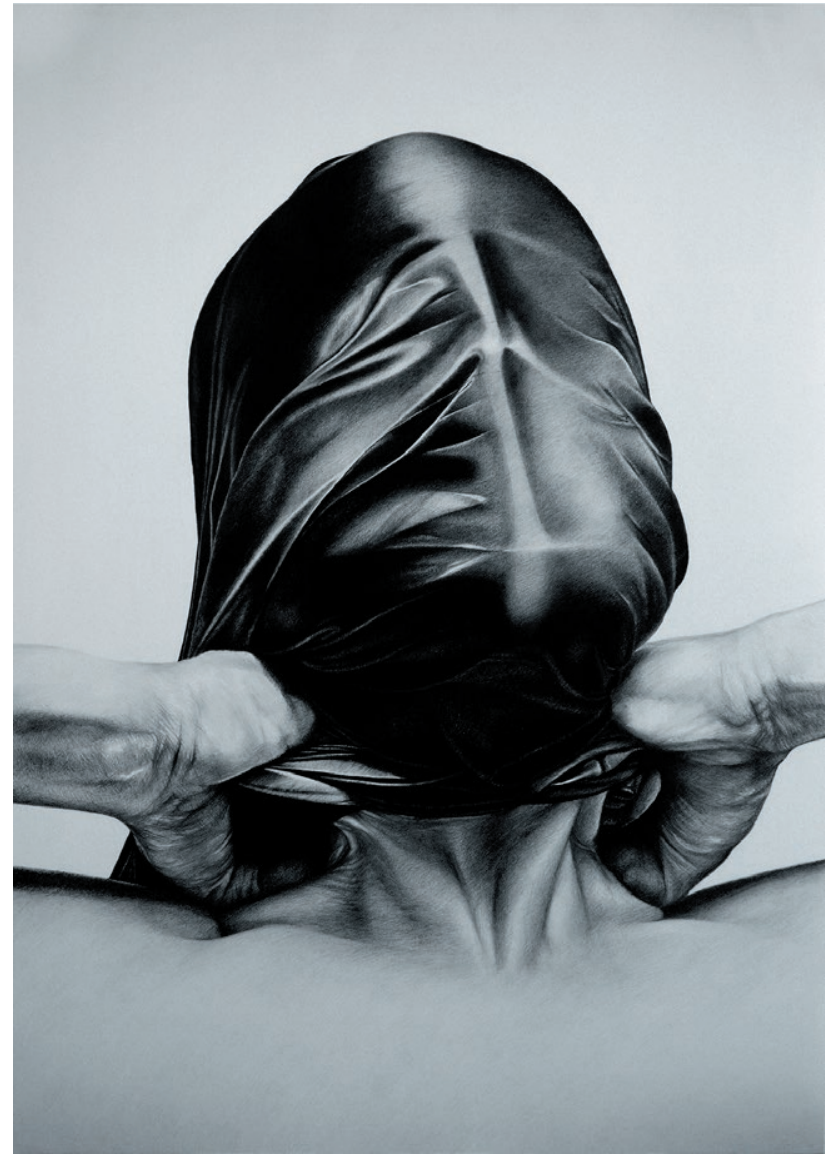

Fig. 6, Sonja Šurbatović, Untitled, 2018, pencil and charcoal on paper, $70 \times 100 \mathrm{~cm}$.

Documenting everything was one of the essential things to keep things in order. Therefore she kept 3 diaries during her life. Written, audio, and drawn. As she stated, that was the way she keeps her house clean. Her parents had a tapestry restoration workshop where she assisted with sewing and repairing, involving her drawing talent, she became valuable in a workshop. Needless to say, that later in her life drawing was meditative in situations submerged in anxiety. She said, her practice was «to give meaning and shape to frustration and suffering» (Wells [2018]). At the time her frustration was depicted, she claimed, that with the finishing drawing, anxiety level would decrease (Hutton [2020]).

A piece that is worth mentioning in the context of lockdown and her state of being is Hours of the Day. The piece from 2006 is made from 25

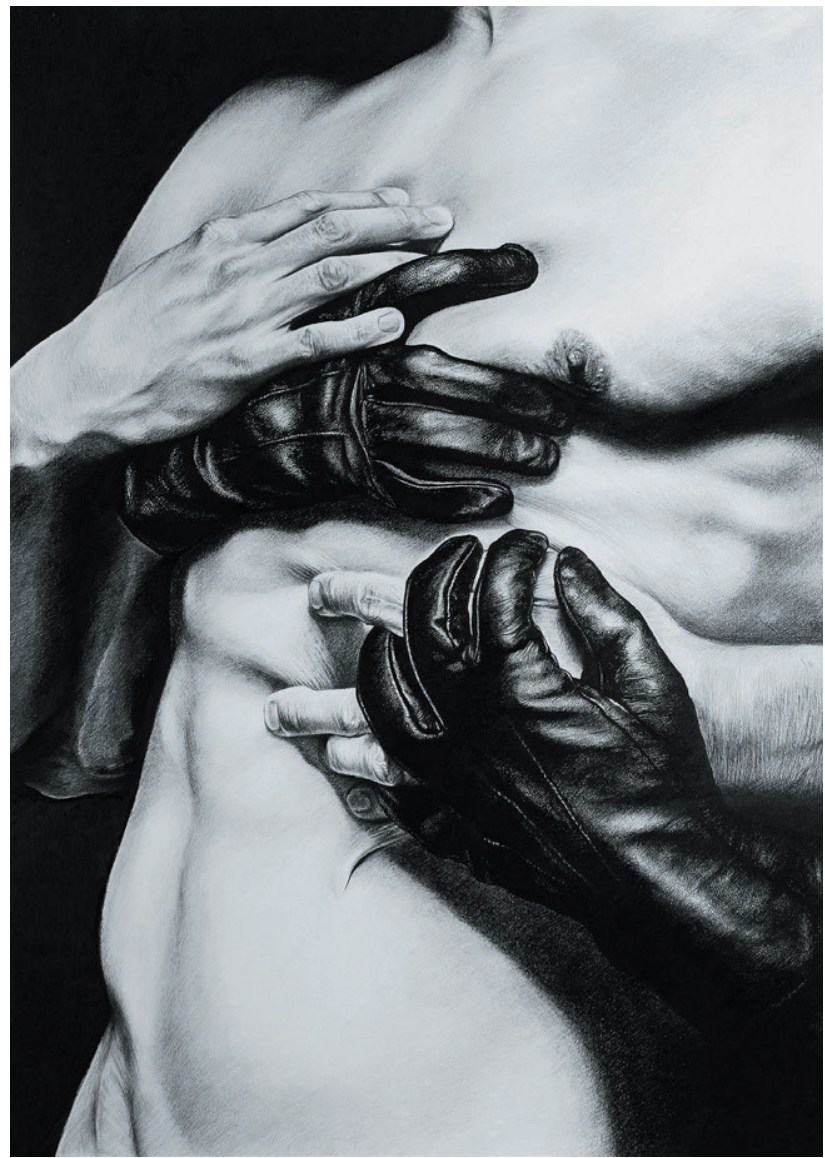

Fig. 7, Sonja Šurbatović, Hug, 2018, pencil and charcoal on paper, $70 \mathrm{x} 100 \mathrm{~cm}$

digital prints supported by fabric and can be seen in form of a book. All the pieces have texts from her daybooks and include the clock as an important element, which shows 24 hours, separated into 24 instead of 12 parts. Only by looking at it, causes discomfort for the observer with its disturbing perspective of time. One of those 25 pieces called, Untitled, no. 2 of 24, holds the text House Artest / Agoraphobia (fig. 11), which is very suggestive and corresponds with the current circumstance.

What is so captivating and obvious in the work of Louise Bourgeois is that they carry an extensive amount of sadness and trauma. Bourgeois frequently used red color for depicting the pain, to represent " involved" in her work - blood, organs, capillaries - and added that the "depth of depression is measured by your attraction to red"» (Wells [2018]). 


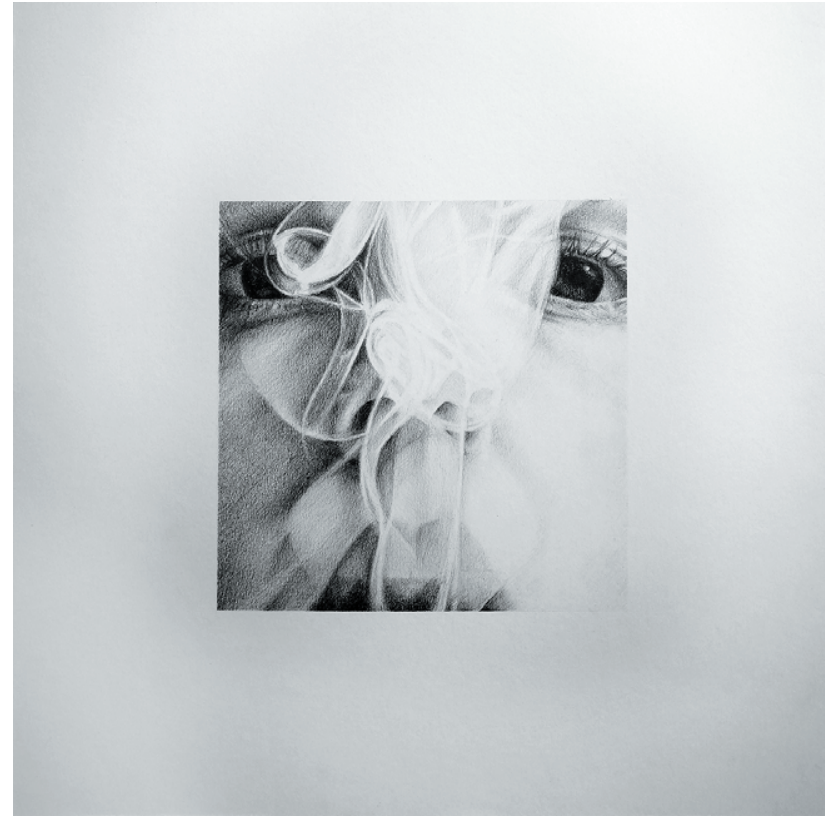

Fig. 8, Sonja Šurbatović, Intimacy 011, 2019, pencil on paper, $30 \times 30 \mathrm{~cm}$.

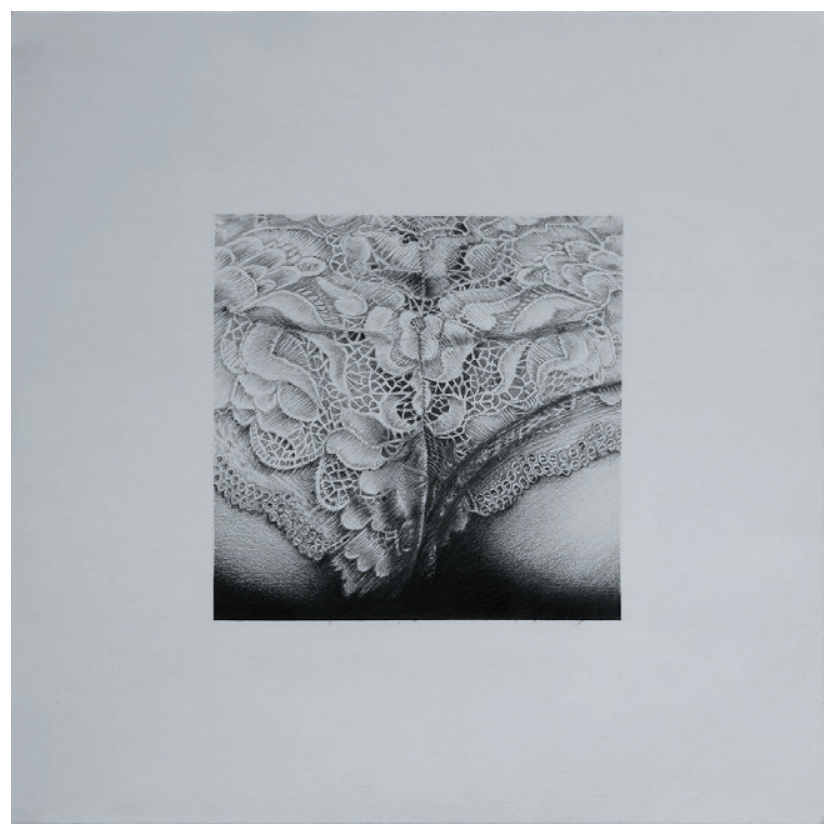

Fig. 9, Sonja Šurbatović, Intimacy 017, 2019, pencil on paper, $30 \mathrm{x} 30 \mathrm{~cm}$.

Another of her works, where red color dominates as intense emotions were involved, represents series of drawings called $10 \mathrm{am}$ is When you Come to Me, (fig. 12). Pieces depict the hands of

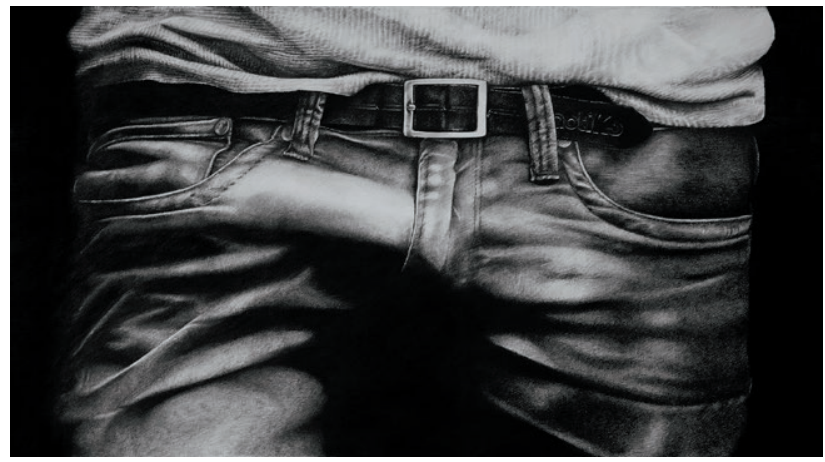

Fig. 10, Sonja Šurbatović, bd.hbts pt. III, 2019, pencil and charcoal on paper $125 \times 70 \mathrm{~cm}$.

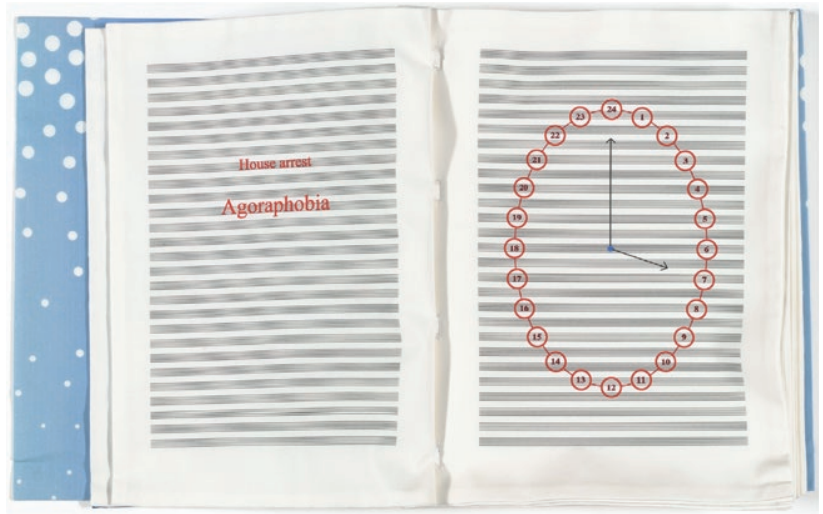

Fig. 11, Louise Bourgeois, Untitled, no. 2 of 24, from the illustrated book, Hours of the Day, 2006 (Copyright () The Easton Foundation/ VAGA at ARS, NY). Retrieved from https://www.moma.org/collection/works/130749? association=illustratedbooks\&page=1\&parent_ id=128387\&sov_referrer=association.

Bourgeois and Jeremy Gorovoy, her assistant and a close friend. 10 was the time when he would come to her studio and start their daily routine, which lasted more than thirty years. They were painted in the technique of gouache on paper. She used hands, limbs, among other bodily forms as motive countless times in her practice. With this work, their mutual trust and support are depicted, through welcoming gestures of touch.

\section{THE LIFE OF A TOUCH}

The urge to touch is identified in a rather early stage of our lives. To describe this impulse is confusing nowadays since the digital age brought 


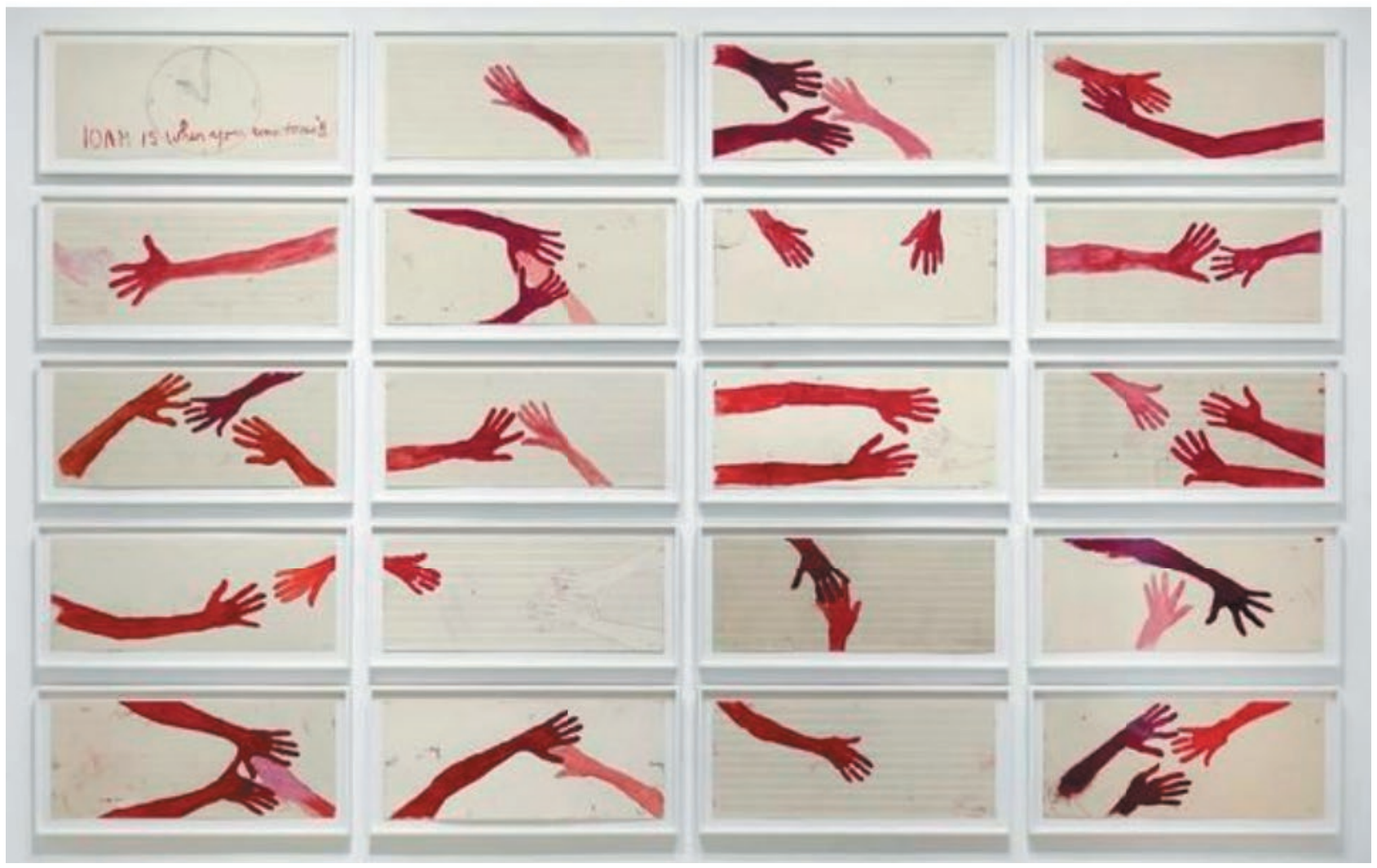

Fig. 12, Louise Bourgeois, 10 AM Is When You Come to Me, 2006-2007. (Copyright $\odot$ The Easton Foundation/VAGA at ARS, NY). Retrieved from https://www.moma.org/s/lb/collection_lb/object/object_objid-204046.html.

us a new approach to senses and habituated acts, a new way of experiencing things. «The point is always made that touch is sequential while vision is comprehensive and instantaneous. The hand must move over and around an object, while the eye can take it in at a glance» (Kleege [2013]: 3). Through scrolling and swiping, we are getting visual sensations by touching. And by that, complete perception is changed. Through culture, touch is constantly redefined. Seen became a new kind of instant statement and way of traversing the senses.

Considering the historical point of view, the matter of touching and owning the image always existed. Religious art, for instance, where closeness to the pictures of the divine scenes, placed the person into a position of the one who is close to God. This imagery, as sometimes believed, was used as relics for healing, too.

We can examine differently, the way touch participated in grasping art. A significant dissent is established whether we talk about touch as $a$ subject of a piece or intention to provoke a tactile sensation in contact with some piece of art, in this particular case, through drawing. Depicting tactile sensation is one of the numerous challenges that even Albrecht Dürer encountered when he tried to paint his sick body, using yellow color, identifying the place of pain. He wanted to communicate the influence of the pain on his body that he felt «That is where it hurts» (Classen [2012]: 126).

As a sensation, touch expresses emotions and associates means to express them. It raises numerous questions concerning proximity, which it is defined by. Aristotle wonders if it is one sense or the group of them, and since it is defined by proximity, unlike other senses (except taste) what is the organ of touching, «is it or is it not the flesh?» (Derrida [2000]: 5).

Diverting insight about the sense of touch is that reviewing the obstacles of social distanc- 
ing and the impossibility of its realization, do we turn to gaze as the only conceivable choice? And how evoking the intimate experience looks like through enclosing it in a drawing. The method of drawing in its basic approach, in this matter, requires commitment. In a physical sense, closeness is required, as well as duration. Like making contact with each other, through this method of drawing, physical contact and reciprocity with the matter are made. With the notion of «reversibility which is always imminent and never realized in fact within seeing and the visible, of the touching and be touched.» Merleau-Ponty questions tactile experience, when we touch are we being touched at the same time (Merleau-Ponty [1964]: 147-148).

In the case of art, using different senses to achieve the experience is desired. It is also crucial since at some point museums and galleries had to preserve the artworks, so touching became forbidden. The link between «seeing by the sense of touch,» and "touch with the sense of sight» was always debatable, in life and art as well (Classen [2012]: 146).

\section{INSTRUMENTS OF DRAWING}

Intruding one's intimacy was always one of the topics that these works rely on. The article written by Terrence Heath about Louise Bourgeois' Insomnia drawings, says, "Drawing itself has an intimacy that most media do not. The drawing is, so to speak, still warm from the hand of the artist. Certainly, this room of drawings has the presence of the artist, not as a star, but as a human being» (Terrence [2004]). As a sketch, it is an immediate response but at the same time, also a deeper devotion.

When everyday routine embraces isolation for the work you are involved with, this new within 4 walls era does not hit so hard. Some studies confirmed that at a certain level we all endured foggy feelings due to pandemics, even basic tasks that we perform on daily basis suffer from forgetting even during mechanical action that occurs.
Reaching back for drawing every day, or better say, feeling the boundaries within the paper and modifying them according to the atmosphere, as a concept has its toll. Materializing the borders makes you think about the situation which enables manipulating and expanding of those boundary lines within the process. The limits of paper, experienced through «touch, embedded in lines and strokes, is one of the dynamic forces that activate the paper space into limitless or controlled depth, assists it to move forward and backward in high or low relief, enwrap objects or recede into vaporous indeterminacy» (Petherbridge [2010]: 116). Drawing becomes a selfexplanatory process by itself.

Through drawing, we can resee missing, giving, sharing, being, and commodifying everything we own and what has been taken from us within a new state of affairs. Indifference is impossible since we all witnessed or experienced, the clear cut within interpersonal relationships and contacts in general. The ones who were lucky enough dodged trembling at work, but most likely, felt it on a personal level. Marking the spaces of the absent one could become an obsession; in an artistic sense, it is loving and deeply caring for the subject matter upon which skill is exercised (Dewey [1980]: 49). Somebody said that pencil is honest. With that thought in mind, the all-day routine could become a lingering confession. Sketching seems too fast, within recent occurrences, something to consume a vaster amount of time, with length and duration is more cherished.

The notion of drawing can never be stripped entirely to the skill, there is always more involved like in any personal interaction. Like with conversation, sometimes you can feel the void, sometimes it is too intense. "Drawing carries out the gesture of its desire» (Nancy [2009]: 25-26). Therefore, shaping is unpredictable. You are making a contact and at the same time, marking the margins, a border around the object, or a person, putting them into the context. For the spectator to read those gestures and marks of a hand drawing, makes it possible for him to comprehend and experience the process of putting it together 
(Petherbridge [2010]: 92). When you are interacting with an individual, you strip them, but at the same time, you strip yourself. The interaction is inevitable.

Inevitably the roles between him and the visible are reversed. That is why so many painters have said that things look at them. As André Marchand says, after Klee:

In a forest, I have felt many times over that it was not I who looked at the forest. Some days I felt that the trees were looking at me, were speaking to me... I was there, listening... I think that the painter must be penetrated by the universe and not want to penetrate it... I expect to be inwardly submerged, buried. Perhaps I paint to break out. (Merleau-Ponty [1947]: 167)

Both sides are almost always equally exposed. And if we're talking about drawing, classical approach with all its high-intensity lines enclosed in it, you have to be there, for that to happen. Proximity is crucial. Whether it is reaching for another, deciphering the resemblance, or making self-reflection, it is always a relation between presence and absence, distance and proximity.

When you face these images, usually showing the close ones, disclosing intimacy to another with its shy gestures, our senses are exerted and studied in this process. It makes you think of possessing them, as Matisse said in Writings on Art, «Drawing is possession. To each line must correspond another line that balances it just as one grasps it, possessing it with two hands» (Nancy [2009]: 18 ). The idea of possessing through the work emerged. Wondering if it is possible, the lines within those pieces, started to give shape for the missing ones, mother, friend, lover.

Visual similarity with certain images, objects, spaces in the aforementioned conditions, in which art was made and absorbed changed, trying to keep, collect, all the moments and memories vivid, by physical contact and activity is enclosed in this work, from drawing in to "drawing out» the integrated experiences of subject and the author (Dewey [1980]: 96). This year which every moment was warped in its every sequence, drawing like it is, with its rudimentary technique, reached a new perspective. Manual, slow, thorough, and timeconsuming unwound as a completely new practice.

Memorizing the people and moments left behind, and that can't be reached currently, is the thread that connects reality and this pseudo-life. Even if online, everything seemed possible, the new context of living makes you re-think experience, a memory of touch and put them into the new context. All those bodies, portraits, and places, dwelling on paper, gained a new dimension since within one room they became rarely preserved spaces you can sense, go into, escape.

Unlike virtual spaces which we invade, where exchanges are inevitable, good or bad, whether we like it or not, drawing is characteristic, since it has a different kind of reflective quality. It penetrates us, even if sometimes doesn't fulfill expectations it is to a certain extent steady, waiting, staring at you. Expecting a response from the spectator as a participant in a process of its identity-making. It doesn't go away with the click, it waits patiently, gives you time, and is imposed through the expectation that you will react.

There is no such thing as just a portrait, or any kind of scene which is deprived of emotion or presence of the other. As Maggi Hambling in one interview said, «Every Portrait Is Like a Love Affair» (Hambling [2018]), and that opinion can be shared. In process of drawing, it is always like in a relationship, there is no pledge. All the time in process of making, remaking it, and having it as one's own. To build and possess, since the attachment to another is jeopardized.

One of my drawings among these corresponds coherently regarding the intrusion of life. It is called Mother ( fig. 1) and could connect frustration caused by the breakup of connections, posing the questions, unveiling doubts and vulnerabilities. This piece originally made full-frontal was named Angst (fig. 2), and even besides the fact that expresses unease, was balanced with a wide white surface embracing it. At the beginning of the quarantine, it was reseen in a state of uncertainty caused by everything that was happening and it is drawn again candidly describing frailty of the being. Strokes were less sensual, like 
thick threads, they kept precision but the depth of the lines ended enclosed in the deep black surface interrupted with the closeness of borders of paper, suggesting cramped space and obscurity of the moment. Describing the process of this practice, can't be compared to something sudden, fast. It is a slow process, more like the unfolding of layers of sentiments, frustration, memories, that are meticulously ordered in sediments of mind. «Most mortals are conscious that a split often occurs between their present living and their past and future. Then the past hangs upon them as a burden; it invades the present with a sense of regret, of opportunities not used, and of consequences, we wish undone» (Dewey [1980]: 16-17). It is not an immediate impact, but a temporal absorption of those events.
The sentiment of disappearing and moving toward the void unconsciously forms the compositions of the drawing; "We don't forget, but something vacant settles in us» (Barthes [2009]: 262). Senses slow down, reactions are delayed. Many of the pieces I made in 2020 are Untitled (fig. 3, 4, 5). Changes in compositions are indicated by external conditions. Indicating distance, inability to touch, saturated black and bold lines establish this relationship with the absent one. Charcoal and paper touching, cancel the dominant narrative imposed from the outside. The collapse of our intimate touch and maintaining the distance reveals another way of reaching each other, "from within that we can approach one another-and the window onto "within" are our

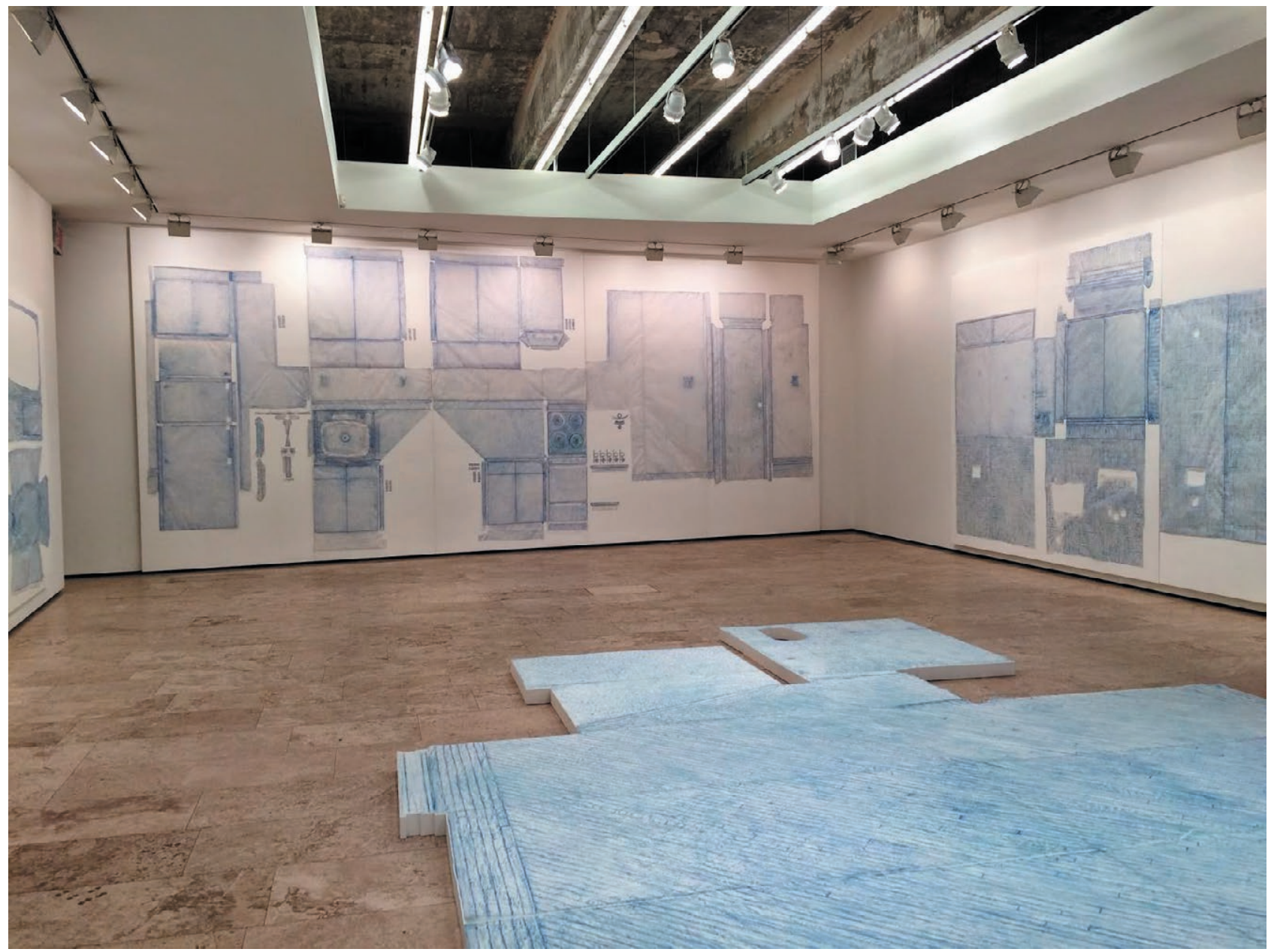

Fig. 13, Do Ho Suh, Rubbing /Loving project, 2016. (Images from Julia Morrisroe - 13 ways of looking at painting blog). Retrieved from https://magpieaesthetic.com/do-ho-suh-rubbing-loving/. 


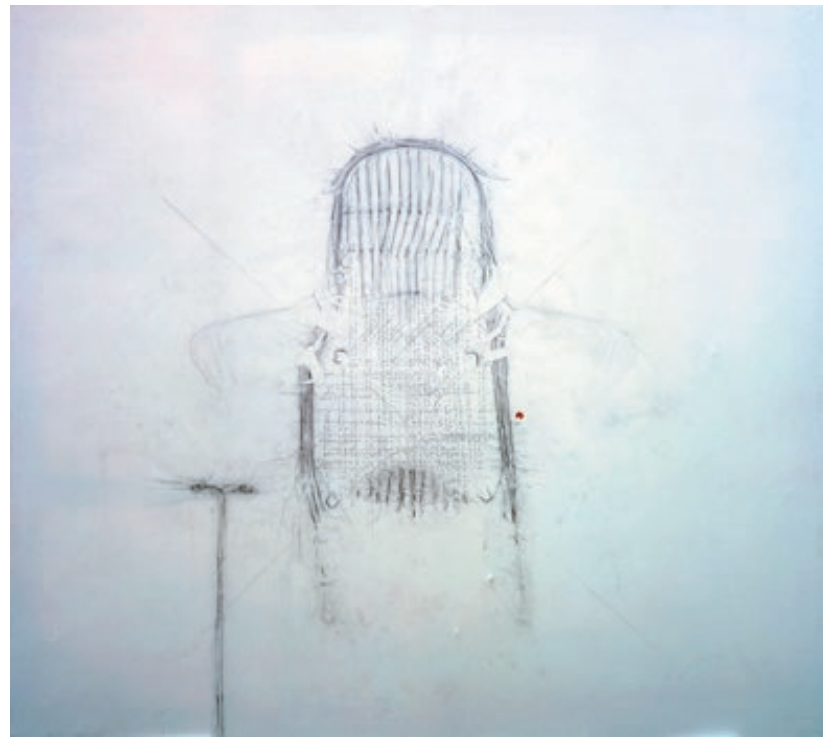

Fig. 14, Alighiero Boetti, Untitled, 1990 (Rachofsky Collection (C) 2012 Estate of Alighiero Boetti/Artists Rights Society (ARS), New York/SIAE, Rome).Retrieved from https://www.moma.org/interactives/exhibitions/2012/boetti/\#null.

eyes» (Žižek [2020]: 1). Commonly these pieces are extensive, dense, with some strange calmness, but during the quarantine, portraits changed. Characters changed, they were not visible anymore like used to, censored themselves, hid in quarantine. The limit drawn became tangible, posing the question whose boundary is it?

Through diverse approaches toward memory and making absence attainable and tangible, we can embrace a couple of artists and their practices. The artist Do Ho Suh memorizes the apartment he leaves after 18 years of living in it, in the technique of frottage. For that project, called Rubbing/Loving (fig. 13), he stated, the gesture of rubbing is a very loving gesture (Forster [2016]). By rubbing he refers to the process of creating the whole space of the apartment in frottage, by transferring an image to paper that was directly pressed to the surface. He wrapped in paper everything that space involved and colored with pencils every element that he left behind, every light switch and doorknob. Embracing the whole apartment he resided in for years, through the medium of drawing, he memorized all the details from the space. Making this ghost space that he

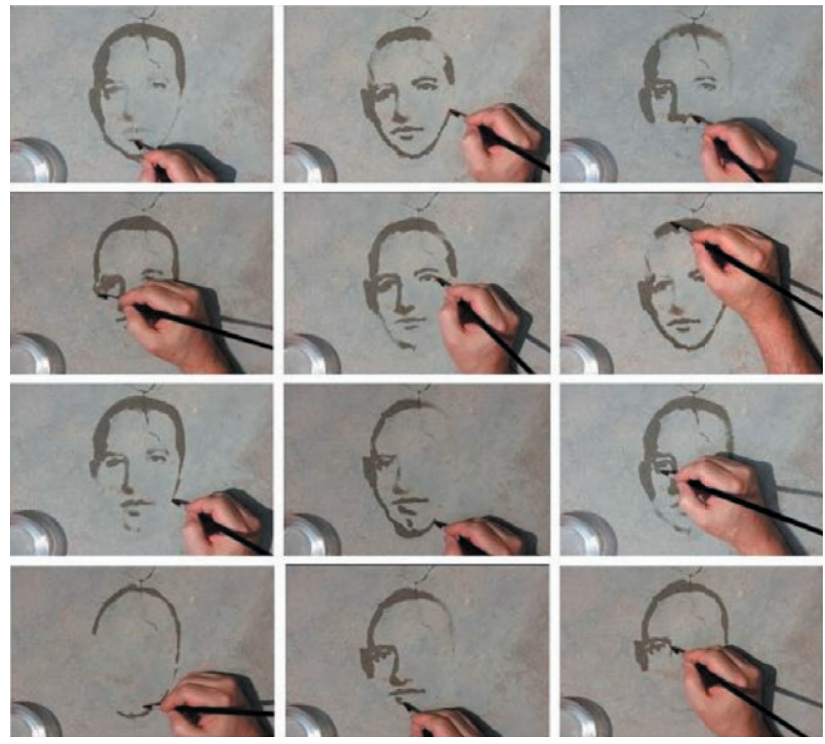

Fig. 15, Oscar Muñoz, Re/trato (Portrait/I Try Again), 2004. (Video projection. 28". Collection of the artist). Retrieved from https://phxart.org/wp-content/uploads/2019/06/Oscar-Munoz-Invisibillia-Curatorial-Statement-for-Web.pdf.

was a piece of, corporeal, he made it become a part of him.

Another interesting example that questions the idea of intangible in the drawing is the Untitled (1990) from the Italian artist Alighiero Boetti (fig. 14), where he is making the study of his body in a chair through performative action. Involving his whole body, he transferred traces of him sitting, on the paper that he wrapped around. By tracing steady shapes of a chair and gentle movements of the artist's body, linear drawing formed. He included a walking stick in this composition to suggest the action, escape from that motionless point (Petherbridge [2010]: 106-107).

Through drawing, shaping particular memories can be various. One more example that portrayed memory through deteriorating media is Colombian artist Oscar Muñoz (fig. 15). He summons familiar concepts, memory among them, depicted with undeniable delicacy. Playing with the concepts of presence/absence he explores the decay of the identity at the same time. Talking about his work, he says it focuses on

the signs of this immemorial setting - the impossibility of definitively retaining and fixing past events- 
and strives as well to provoke memory by using a similar device, that is, by focusing on impermanence and the intangible. Invariably employing the photographic act and its chemical nature as both reference and metaphor, and centering especially on the genre of portraiture. (Davidson, Lampe [2019]).

All the examples above mentioned, discuss the drawing as means for deciphering and eliminating fears, in the case of Louise Bourgeois e.g., and at the same time, drawing is used as a mechanism to preserve the memory or challenge identities. Testimony, whether we talk about a sketch or something more elaborated, drawing can't be observed only as an instrument, because it is evident that it is a manifold purpose, it's a product, objective, fulfillment in some sense, depending on perspective. Faced with decoding intimacy through drawing, we could say it is ticklish because it blurs memories, feelings, and questions the veracity of the subject, moment, or feeling they generate in the process of drawing.

\section{CONCLUSION}

Drawing as a medium of choice no matter how outdated may seem provides an aesthetic experience, that we can grasp immediately. As David Lynch said, in movies today everything is fast and the quality of slow is lost. But the slow can pose the question, how close can we get? In the time when the touch is bleached out, to offer it or experience it as a more profound sense is becoming an indulgence on its own.

Experiencing corporeal distance that parts us from the ones we love or denies us our usual comforts, offers a possibility to seize things differently. It's up to us are we going to benefit from this collective escapism, and learn something useful from global events, or keep the same old tainted narratives. Are we going to embrace moments differently in the future? Those, until yesterday, common events, essential touches, like a handshake, hug. Perhaps drawing, even sometimes perceived as a mastodon of artistic expression, stays persistent in this fluid epoch to preserve the idea of slow and calm. Deepening the void formed by this solitude, to display and remind us of something forgotten or overlooked, that we may nurture for tomorrow.

\section{REFERENCES}

Merriam-Webster. (n.d.). 2021 : Absence. In Merriam-Webster.com dictionary, last accessed June 7 2021, https://www.merriam-webster.com/dictionary/absence

Foucault, M., 1977: Discipline and Punish. The Birth of the Prison, Vintage Books, New York, 1995.

Deleuze, G., 1992: Postscript on the Societies of Control, "October", 59, pp. 3-7.

Classen, C., 2012: The Deepest Sense: A Cultural History of Touch, University of Illinois Press, Urbana, Chicago, and Springfield.

Petherbridge, D., 2010, The Primacy of Drawing, Yale University Press, New Haven and London.

Derrida, J., 2000: On Touching - Jean-Luc Nancy, Stanford University Press, Stanford, CA, 2005.

Nancy, Jean-Luc, 2009: The Pleasure in Drawing, Fordham University Press, New York, 2013.

Merleau-Ponty, M., 1947: The Primacy of Perception, Northwestern University Press, Chicago, 1964.

Merleau-Ponty, M., 1964: The Visible and the Invisible, Northwestern University Press, Chicago, 1968.

Žižek, S., 2020: Pandemic!, Polity Press, New York.

Barthes, R., 2009: Mourning Diary, Hill and Wang, New York, 2010.

Dewey, J., 1980: Art as Experience, The Berkley Publishing Group, New York, 2005.

Kleege, G., 2013: Some Touching Thoughts and wishful Thinking,

“Disability Studies Quarterly" Vol. 33, No. 3, 2013, last accessed June 7 2021, https://dsq-sds.org/ article/view/3741/3284

Smith, R., 2017: Louise Bourgeois: Imagination Unfolds in All Dimensions, "The New York Times, September 2, last accessed June 72021 , https://www.nytimes.com/2017/09/27/arts/ 
design/louise-bourgeois-imagination-unfoldsin-all-dimensions.html

Wells, E., 2018: The Subject of Pain is the Business I am In, "Artillery Magazine" March 15, last accessed June 7 2021, https://artillerymag.com/ subject-pain-business/

Hutton, B., 2020: How Louise Bourgeois Used Drawing to Alleviate Anxiety, "Anothermag" March 25, last accessed June 7 2021, https:// www.anothermag.com/art-photography/12375/ louise-bourgeois-drawings-anxiety-hauserwirth-online-exhibition

Heath, T., 2004: Louise Bourgeois [The Insomnia Drawings. Whitney Museum of Aamerican Art. New York], "Border Crossings", 23, 91-92.

Forster, I., 2016: Do Ho Suh Memorializes His New York Apartment, "Art21 Magazine", December 9, last accessed June 7 2021, http://magazine. art21.org/2016/12/09/do-ho-suh-memorializes-his-new-york-apartment/\#.YGb81BMzbOR

Davidson, V., Lampe, J., Lampe, S., 2019: Oscar Muñoz: Invisibilia. Phoenix Art Musem. 2021. Retrieved from https://phxart.org/exhibition/ oscar-munoz-invisibilia/

Hambling , M., 2018: Every Portrait is Like a Love Affair, Artist Interview, TateShots, last accessed June 7 2021, https://www.youtube.com/ watch?v=M4-4Syn $1 \mathrm{pmE}$ 